\title{
ФIHAHCOBE ПРABO
}

\section{ОСОБЛИВОСТІ ОПОДАТКУВАННЯ ПІДПРИЕМСТВ АГРОПРОМИСЛОВОГО КОМПЛЕКСУ В УКРАЇНІ}

\author{
С.В. СЛЮСАРЕНКО, кандидат юридичних наук, доцент, \\ доцент кафедри адміністративного та фрінансового права, \\ Національний університет біоресурсів і природокористування України \\ E-mail: sergiy.sliusarenko@gmail.com \\ O.В. АРТЕМЕНКО, кандидат юридичних наук, дочент, \\ доцент кафедри адміністративного та фінансового права, \\ Національний університет біоресурсів і природокористування України \\ E-mail: artolena11@ukr.net
}

\begin{abstract}
Анотація. Стаття присвячена дослідженню проблем оподаткування підприємств агропромислового комплексу в Україні. Розглянуто особливості податкового регулювання сільськогосподарських підприємств. Проаналізовано історичні етапи розвитку сільськогосподарського податку та досліджено теперішній стан системи оподаткування аграрних підприємств. Визначені основні елементи податків для підприємств аграрного сектору: платники податку; об'єкти оподаткування; база оподаткування; ставка податку; порядок обчислення податку; податковий період; строк та порядок сплати податку; строк та порядок подання звітності про обчислення і сплату податку.

Ключові слова: оподаткування, сільськогосподарський товаровиробник, спрощена система оподаткування, єдиний податок, земельний податок, податок на прибуток, податок на додану вартість
\end{abstract}

\section{Актуальність.}

Аграрний сектор посідає важливе місце в економіці суспільства. Сільське господарство є великою бюджетоутворюючою галуззю в економіці країни. Від розвитку аграрного сектора залежить нормальне функціонування всього господарства країни і добробут людей.
А розвиток самого аграрного сектора значною мірою залежить від ефективного оподаткування, що $є$ основою для віднайдення шляхів удосконалення найефективнішого розвитку АПК. 3 огляду на сезонність та високий ризик сільськогосподарських товаровиробників, оподаткування агропромислових підприємств завжди було одним із 
особливих видів податкових відносин, сільськогосподарські товаровиробники завжди потребували державної підтримки та захисту від зовнішньої конкуренції оскільки система оподаткування $\epsilon$ важливим механізмом стимулювання економічного зростання та визначає конкурентоспроможність вітчизняної продукції на світових ринках.

\section{Аналіз останніх досліджень та публікацій.}

Розкриттям аспектів сутності оподаткування підприємств агропромислового комплексу в цілому обгрунтовувалися у наукових працях такими вченими, як: О.Ю. Буцькою, П.І. Коренюком, О.В. Олійником, А.В. Поляком, Л.Д. Тулуш та деякими іншими науковцями.

Метою статmі є окреслення проблем оподаткування підприємств агропромислового комплексу в Україні.

\section{Результати.}

Одним із головних завдань у процесі здійснення економічної реформи в агропромисловому комплексі $є$ формування ефективного податкового механізму як одного з інститутів ринкової економіки, що дає змогу, з одного боку, розв'язувати проблему збільшення доходів бюджетів різних рівнів, $з$ другого - сприяти поступальному розвитку господарюючих суб'єктів як агропромислової сфери, так i економіки загалом. Ключові чинники в економічній сфері АПК нині - це податки і приватні інвестиції. Без перших неможливі погашення зовнішнього боргу і забезпечення хоча б мінімальних соціальних гарантій (особливо це важливо для сільських територій), без других реструктуризація агропромисловості та вихід на траєкторію сталого економічного зростання, з вищими показниками.
Проте, і в тому, і в іншому випадку всі економічні агенти повинні мати стимули і спроможність платити податки, а також інвестувати і зберігати кошти в легальних і цивілізованих формах (Коренюк, 2018). АПК - це система соціально-економічних цінностей пов'язана із забезпеченням суспільства продуктами харчання, до складу якого входить сільське господарство (рослинництво і тваринництво), сфери його переробки, відповідна інфраструктура, сільськогосподарське машинобудування та спеціальні забезпечувальні суб' єкти (будівництво, торгівля, харчування, хімія, освіта).

Слід вказати, що процес формування системи оподаткування на теренах сучасної України розпочався ще за часів Київської Русі. Закладені в ті часи основи податкової системи, пройшовши тривалий шлях змін і вдосконалення протягом багатьох століть, відіграли важливу роль під час побудови сучасної системи податкових органів України (Поляк, 2016: 86). Вітчизняний податковий механізм у сільському господарстві вже друге десятиріччя направлений на виконання особливого, не притаманного, по суті, йому завдання - стимулювання розвитку сільськогосподарських товаровиробників шляхом створення сприятливого податкового середовища, формування специфічного джерела фінансових ресурсів. Причиною цього є відсутність у держави можливостей застосування більш дієвого інструментарію фінансової підтримки.

В цьому контексті слід зазначити, що оподаткування сільськогосподарських товаровиробників 3 часу формування податкової системи України стало особливою сферою взаємовідносин із державою, що слабо корелювала 3 народногосподарською системою оподаткування. Йому властиве функ- 
ціонування особливих податкових інструментів та наявність спеціальних режимів оподаткування, що дозволяють спростити податкові процедури та стимулювати розвиток сільськогосподарської діяльності (Тулуш, 2008). В Україні до 2010 р. оподаткування сільськогосподарських підприємств здійснювалося згідно з Законом України «Про оподаткування прибутку підприємств», «Про ПДВ», «Про плату за землю» та інших законів. Також сільськогосподарські підприємства здійснювали оподаткування своєї діяльності згідно з Законом України «Про фіксований сільськогосподарський податок». 3 прийняттям Податкового кодексу України законодавець в ст. 155 ПКУ визначив, що підприємства, основною діяльністю яких є виробництво сільськогосподарської продукції, сплачують податок у порядку і в розміpax, передбачених ПКУ, за підсумками звітного податкового року. Для цілей оподаткування до підприємств, основною діяльністю яких $\epsilon$ виробництво сільськогосподарської продукції, належать підприємства, дохід яких від продажу сільськогосподарської продукції власного виробництва за попередній звітний (податковий) рік перевищує 50 відсотків загальної суми доходу. Для підприємств АПК залишалися майже ті самі умови, як і до прийняття Податкового кодексу України.

У систему податкового стимулювання аграрного сектору входив запроваджений з 1999 р. по 2015 р. фіксований сільськогосподарський податок (тепер єдиний податок), спеціальний режим в оподаткуванні діяльності сільськогосподарських підприємств, що діяв до 2017 р., та компенсація заходів аграріям, що працюють на спрощеній системі оподаткування (Олійник \& Скоромна, 2016).
Також до 2015 р. суб'єктам господарювання, які здійснювали діяльність в аграрній сфері (зокрема, у сфері сільського, лісового господарства та рибальства), перебували на загальній системі оподаткування і відповідали встановленим критеріям, було надано право використовувати спеціальний режим оподаткування ПДВ. Його особливість полягала в тому, що сума податку, яка нараховувалася на вартість поставлених сільськогосподарських товарів/послуг власного виробництва, не сплачувалася до бюджету, а повністю залишалась у розпорядженні товаровиробника 3 метою відшкодування податку за придбані товари/послуги, з яких сформовано податковий кредит, а у разі наявності залишку використовувалась на виробничі цілі.

Скасування спеціального режиму ПДВ відбувалося у два етапи. На першому етапі (протягом 2016 р.) у розпорядженні сільськогосподарського товаровиробника залишалася частка суми ПДВ, розмір якої залежав від галузі виробництва. Пп. 209.2.2 п. 209.2 ст. 209 ПКУ було встановлено, що за операціями 3 сільськогосподарськими товарами/ послугами (крім операцій із зерновими й технічними культурами та операцій 3 продукцією тваринництва) на спеціальних рахунках, відкритих сільськогосподарським підприємствам, залишається 50 \% від суми ПДВ; за операціями із зерновими та технічними культурами $15 \%$; за операціями $з$ продукцією тваринництва - 80 \%. Ці суми залишалися у розпорядженні сільськогосподарського підприємства для використання у виробництві сільськогосподарських товарів/послуг (Навальнев, 2018).

31 січня 2015 р. ст. 155 ПКУ втратила чинність, вступила в дію нова податкова реформа, яка відобразила свій вплив в тому числі і на аграрний 
сектор України. Для сільського господарства замість фіксованого сільськогосподарського податку запроваджено єдиний податок для платників четвертої групи. Як свідчать деякі спеціалісти, ці зміни досить формальні: відбулося формальне включення фіксованого сільгоспподатку до складу єдиного податку. Самі правила оподаткування сільськогосподарських товаровиробників майже не змінилися (Сідоренко).

Для того щоб опинитися на загальній системі оподаткування, не потрібно застосовувати ніяких зусиль - будь-яке нове аграрне підприємство автоматично стає на загальні рейки оподаткування (Коренюк, 2018).

Використовуючи у своїй діяльності загальну систему оподаткування обліку і звітності сільськогосподарські товаровиробники сплачують всі без винятку податки і збори, визначені Податковим кодексом України. Такий режим оподаткування не сприяє державній підтримці та створенню особливих пільгових умов для товаровиробників. При цьому основними податками, що сплачуються, є податок на прибуток підприємства, податок на додану вартість, плата за землю, податок на доходи фізичних осіб. Окрім того підприємства аграрного сектору можуть бути платниками i інших податків, за умови наявності у них об'єктів оподаткування. Вагомим недоліком цієї системи оподаткування $є$ значне податкове навантаження на платників (Буцька, 2017).

Проте, за умови виконання встановлених Податковим кодексом України вимог сільськогосподарські підприємства мають право використовувати спеціальний податковий режим і бути платниками єдиного податку на IV групі оподаткування.
Сільськогосподарські підприємства які перейшли на IV групу єдиного податку звільняються від обов'язку нарахування, сплати та подання податкової звітності з таких податків і зборів:

1) податку на прибуток підприємств; 2) податку на доходи фізичних осіб у частині доходів (об'єкта оподаткування), що отримані в результаті господарської діяльності платника єдиного податку першої - четвертої групи (фізичної особи);

3) податку на майно в частині земельного податку за земельні ділянки для ведення сільськогосподарського товаровиробництва;

4) рентної плати за спеціальне використання води (Податковий кодекс України, 2010).

Сільськогосподарські товаровиробники для переходу на спрощену систему оподаткування або щорічного підтвердження статусу платника єдиного податку подають не пізніше 20 лютого поточного року:

загальну податкову декларацію 3 податку на поточний рік щодо всієї площі земельних ділянок, 3 яких справляється податок (сільськогосподарських угідь (ріллі, сіножатей, пасовищ, багаторічних насаджень), та/ або земель водного фонду внутрішніх водойм (озер, ставків та водосховищ), - контролюючому органу за своїм місцезнаходженням (місцем перебування на податковому обліку);

звітну податкову декларацію з податку на поточний рік окремо щодо кожної земельної ділянки - контролюючому органу за місцем розташування такої земельної ділянки (юридичні особи);

розрахунок частки сільськогосподарського товаровиробництва (юридичні особи) - контролюючим органам за своїм місцезнаходженням та/або за 
місцем розташування земельних ділянок за формою, затвердженою центральним органом виконавчої влади, що забезпечує формування державної аграрної політики, за погодженням із центральним органом виконавчої влади, що забезпечує формування та реалізує державну фінансову політику;

відомості (довідку) про наявність земельних ділянок - контролюючим органам за своїм місцезнаходженням та/або за місцем розташування земельних ділянок (Податковий кодекс України, 2010).

Платники єдиного податку четвертої групи можуть самостійно перейти на застосування ставки єдиного податку, визначеної для платників єдиного податку іншої групи, або відмовитися від спрощеної системи оподаткування у зв'язку з переходом на сплату інших податків і зборів, визначених Податковим Кодексом, 3 першого числа місяця, наступного за податковим (звітним) кварталом, у якому подано відповідну заяву у порядку згідно з пунктом 298.2 ст. 298 ПКУ, за умови сплати податку за поточний рік у розмірі, що розраховується виходячи з 25 відсотків річної суми податку за кожний квартал, протягом якого платник перебував на четвертій групі платників єдиного податку.

Згідно зі ст. 298.8.8 сільськогосподарський товаровиробник повторно може бути включений до четвертої групи платників єдиного податку не раніше ніж через два календарні роки після його переходу на застосування ставки єдиного податку, визначеної для платників єдиного податку іншої групи, або анулювання його попередньої реєстрації платником єдиного податку четвертої групи.

Відповідно до ст. 292-1.1 об'єктом оподаткування для платників єдиного податку четвертої групи $є$ площа сільськогосподарських угідь (ріллі, сіножатей, пасовищ і багаторічних насаджень) та/або земель водного фонду (внутрішніх водойм, озер, ставків, водосховищ), що перебуває у власності сільськогосподарського товаровиробника або надана йому у користування, у тому числі на умовах оренди.

Базою оподаткування податком для платників єдиного податку четвертої групи для сільськогосподарських товаровиробників $є$ нормативна грошова оцінка 1 гектара сільськогосподарських угідь (ріллі, сіножатей, пасовищ i багаторічних насаджень) з урахуванням коефіцієнта індексації, визначеного станом на 1 січня базового податкового (звітного) року відповідно до порядку, встановленого Податковим Кодексом для справляння плати за землю.

У разі якщо нормативна грошова оцінка земельної ділянки не проведена, базою оподаткування податком для платників єдиного податку четвертої групи для сільськогосподарських товаровиробників $є$ нормативна грошова оцінка одиниці площі ріллі в Автономній Республіці Крим або області.

Базою оподаткування податком для платників єдиного податку четвертої групи для земель водного фонду (внутрішніх водойм, озер, ставків, водосховищ) $є$ нормативна грошова оцінка ріллі в Автономній Республіці Крим або області з урахуванням коефіцієнта індексації, визначеного станом на 1 січня базового податкового (звітного) року відповідно до порядку, встановленого Податковим Кодексом для справляння плати за землю. Для платників єдиного податку четвертої групи розмір ставок податку з одного гектара сільськогосподарських угідь та/або земель водного фонду залежить від категорії (типу) земель, їх розташування. 
Отже, бачимо, що Податковий Кодекс передбачає право вибору сільськогосподарським підприємствам самостійно відмовитися від спрощеної системи оподаткування у зв'язку 3 переходом на сплату інших податків i зборів. Для обрання або переходу на спрощену систему оподаткування суб' єкт господарювання подає до контролюючого органу за місцем податкової адреси заяву.

Оподаткування аграрних підприємств в Україні які обирають загальну систему здійснюється на загальних умовах, такі підприємства зобов'язані сплачувати податок на прибуток, податок на додану вартість, податок на майно (земельний податок), рентну плату.

Для цілей оподаткування податком на прибуток до підприємств, основною діяльністю яких є виробництво сільськогосподарської продукції, належать підприємства, дохід яких від продажу сільськогосподарської продукції власного виробництва за попередній податковий (звітний) рік перевищує 50 відсотків загальної суми доходу.

Оподаткування сільськогосподарських товаровиробників податком на прибуток здійснюється на загальних умовах за ставкою $18 \%$. Але особливістю для виробників сільськогосподарської продукції $є$ те, що законодавець передбачив в 2020 р. можливість обирати річний податковий (звітний) період, який починається 31 липня минулого звітного року і закінчується 30 червня поточного звітного року (Про внесення змін до Податкового кодексу України..., 2020).

Новелою оподаткування сільськогосподарських товаровиробників ПДВ є те, що згідно з п. 63 підрозд. 2 розд. ХХ ПКУ, тимчасово звільняються від оподаткування ПДВ операції з вивезення за межі митної території України в митному режимі експорту: з 01.09.2018 р. до 31.12.2021 р. соєвих бобів; з 01.01.2020 р. до 31.12.2021 p. насіння свиріпи або ріпаку. Наведені положення не поширюються на сільськогосподарські підприємства виробників соєвих бобів та насіння свиріпи чи ріпаку, вирощених ними на землях сільськогосподарського призначення, які перебувають у власності таких товаровиробників чи в їхньому постійному користуванні або використовуються ними на правах оренди (суборенди) чи емфітевзису.

Аналізуючи останнє положення, слід звернути увагу на те, що воно не розповсюджуються на сільськогосподарські підприємства, які самостійно виростили зазначені культури та експортують їх, а тому мають право на таке бажане відшкодування ПДВ (Навальнєв, 2018). Також 25 лютого 2021 р. набули чинності зміни до Податкового кодексу України щодо зниження ставки ПДВ $20 \%$ до $14 \%$ на операції з імпорту та постачання на території України деякої сільськогосподарської продукції (Про внесення змін до Податкового кодексу України..., 2020). Ставка $14 \%$ застосовується, починаючи 31 березня 2021 р. для продукції тваринного та рослинного походження для деяких видів товарних позицій з УКТ ЗЕД передбаченим законодавством.

Підприємства якщо $є$ власниками земельних ділянок, земельних часток (паїв) або землекористувачами також сплачують земельний податок. Як передбачає податкове законодавство, він $\epsilon$ однією із форм плати за землю (п.п. 14.1.147 ПКУ). В свою чергу, плата за землю - це одна із складових податку на майно (п.п. 265.1.3 ПКУ). А тому, наразі земельний податок $є$ місцевим (п.п. 10.1.1 ПКУ), а не загальнодержавним (як це було до 2015 р.) (Земельний податок, 2016). Більше того, він є обов'яз- 
ковим самостійним елементом сучасної системи оподаткування та стабільним джерелом надходжень до бюджетної системи України (Богдан, 2001). Особливості справляння податку суб'єктами господарювання, які застосовують спрощену систему оподаткування, обліку та звітності, встановлюються главою 1 розділу XIV ПКУ.

\section{Висновки і перспективи.}

Увесь вище наведений матеріал дає змогу підбити підсумок. Дійсно, сьогодні ні для кого не секрет, що система оподаткування в АПК потребує змін. Основна мета - зробити іï оптимальною та прийнятною як для держави, так і для аграріїв, спростити систему адміністрування податків, зберегти прогнозованість на наступні роки. Для ефективної діяльності підприємств АПК в Україні, щоб мати конкуренті умови як на зовнішньому так і на внутрішньому ринку, законодавець має передбачати різноманітну державну підтримку, в першу чергу малих сільськогосподарських товаровиробників у фіскальній сфері, включаючи існування певних податкових пільг.

\section{Список використаних джерел}

1. Коренюк П.І. Особливості податкового регулювання аграрного сектору. Гроші, фінанси і кредит. 2018. 20. С. 237-242.

2. Поляк А.В. Становлення й розвиток податкових органів на українських землях. Вісник Запорізького національного університету. Юридичні науки. 2016. № 2. С. 78-86.

3. Тулуш Л.Д. Розвиток системи оподаткування сільськогосподарських товаровиробників в умовах членства України в СОТ. Облік і фінанси АПК: бухгалтерський портал. 2008. URL: http://magazine.faaf. org.ua/rozvitok-sistemi-opodatkuvannya- silskogospodarskih-tovarovirobnikiv-vumovah-chlenstva-ukraini-v-sot.html (дата звернення: 18.03.2021р.).

4. Олійник О.В., Скоромна О.Ю. Зміни в системі оподаткування та їх вплив на тенденції економічного розвитку аграрного сектора економіки. Вісник ХНАУ. Серія: Економічні науки. 2016. № 2. С. 285-291.

5. Навальнєв О. Оподаткування агробізнесу: останні новели. Юридична газета. 2018. № 43-44. С. 645-646.

6. Сідоренко Р.В. Оподаткування діяльності сільськогосподарських підприємств: сучасний стан та перспективи розвитку. URL: http://bses.in.ua/ journals/2016/12-2_2016/34.pdf. (дата звернення: 18.03 .2021 р.).

7. Буцька О.Ю. Оподаткування сільськогосподарських підприємств в умовах податкових змін. Електронний журнал «Ефективна економіка». 2013. № 12. URL: http://www. economy.nayka.com.ua/?op $=1 \& z=2579$ (дата звернення: 18.03.2021р.).

8. Податковий кодекс України від 02.12.2010 p. № 2755-VI. URL: https:// zakon.rada.gov.ua/laws/show/275517\#Text (дата звернення: 18.03.2021р.).

9. Про внесення змін до Податкового кодексу України щодо вдосконалення адміністрування податків, усунення технічних та логічних неузгодженостей у податковому законодавстві: Закон України від 16.01.2020 р. № 466-ІХ.

10. Про внесення змін до Податкового кодексу України щодо ставки податку на додану вартість з операцій з постачання окремих видів сільськогосподарської: Закон України від 17.12.2020 р. № 1115-ІХ.

11. Земельний податок - 2016. Відомості із сайту «Бухгалтер». 2016. URL: https:// buhgalter.com.ua/articles/podatky-tazbory/zemelniy-podatok-2016/ (дата звернення: 18.03.2021р.).

12. Богдан А. Справляння плати за землю в Україні. Вісник податкової служби України. 2001. № 31. С. 41-52. 


\section{References}

1. Koreniuk, P.I. (2018). Osoblyvosti podatkovoho rehuliuvannia ahrarnoho sektoru. Hroshi, finansy i kredyt [Features of tax regulation of the agricultural sector.], 20: 237-242 (in Ukrainian).

2. Poliak, A.V. (2016). Stanovlennia y rozvytok podatkovykh orhaniv na ukrainskykh zemliakh. Visnyk Zaporizkoho natsionalnoho universytetu. Yurydychni nauky [Formation and development of tax authorities on Ukrainian lands. Bulletin of Zaporizhia $\mathrm{Na}-$ tional University. Legal sciences], 2: 78-86 (in Ukrainian).

3. Tulush, L.D. (2008). Rozvytok systemy opodatkuvannia silskohospodarskykh tovarovyrobnykiv $v$ umovakh chlenstva Ukrainy $v$ SOT. Oblik i finansy APK: bukhhalterskyi portal [Development of the system of taxation of agricultural producers in the conditions of Ukraine's membership in the WTO. Accounting and finance of agro-industrial complex: accounting portal]. Available at: http://magazine.faaf.org.ua/rozvitok-sistemi-opodatkuvannya-silskogospodarskih-tovarovirobnikiv-v-umovah-chlenstva-ukraini-v-sot.html (in Ukrainian).

4. Oliinyk, O.V. \& Skoromna, O.Yu. (2016). Zminy $v$ systemi opodatkuvannia ta yikh vplyv na tendentsii ekonomichnoho rozvytku ahrarnoho sektora ekonomiky. Visnyk KhNAU. Seriia: Ekonomichni nauky [Changes in the taxation system and their impact on the trends of economic development of the agricultural sector of the economy. Bulletin of KhNAU. Series: Economic Sciences], 2: 285-291 (in Ukrainian).

5. Navalniev, O. (2018). Opodatkuvannia ahrobiznesu: ostanni novely. Yurydychna hazeta [Agribusiness taxation: recent stories. Legal newspaper], 43-44: 645-646 (in Ukrainian).

6. Sidorenko, R.V. Opodatkuvannia diialnosti silskohospodarskykh pidpryiemstv: suchasnyi stan ta perspektyvy rozvytku
[Taxation of agricultural enterprises: current status and development prospects]. Available at: http://bses.in.ua/journals/2016/12-2_2016/34.pdf. (in Ukrainian).

7. Butska, O.Yu. (2013). Opodatkuvannia silskohospodarskykh pidpryiemstv $v$ umovakh podatkovykh zmin. Elektronnyi zhurnal «Efektyvna ekonomika» [Taxation of agricultural enterprises in terms of tax changes. E-journal "Effective Economy»], 12. Available at: http://www.economy.nayka. com.ua/?op=1\&z=2579 (in Ukrainian).

8. Podatkovyi kodeks Ukrainy [Tax Code of Ukraine] (2010) 02.12.2010 № 2755-VI. Available at: https://zakon.rada.gov.ua/ laws/show/2755-17\#Text (in Ukrainian).

9. Pro vnesennia zmin do Podatkovoho kodeksu Ukrainy shchodo vdoskonalennia administruvannia podatkiv, usunennia tekhnichnykh ta lohichnykh neuzghodzhenostei u podatkovomu zakonodavstvi [On amendments to the Tax Code of Ukraine to improve tax administration, eliminate technical and logical inconsistencies in tax legislation] (2020): Zakon Ukrainy 16.01.2020 № 466-IX (in Ukrainian).

10. Pro vnesennia zmin do Podatkovoho kodeksu Ukrainy shchodo stavky podatku na dodanu vartist $z$ operatsii z postachannia okremykh vydiv silskohospodarskoi [On amendments to the Tax Code of Ukraine regarding the rate of value added tax on transactions for the supply of certain types of agricultural] (2020): Zakon Ukrainy 17.12.2020 № 1115-IX (in Ukrainian).

11. Zemelnyi podatok - 2016. Vidomosti iz saitu "Bukhhalter» [Land tax - 2016. Information from the site "Accountant»] (2016). Available at: https://buhgalter.com. ua/articles/podatky-ta-zbory/zemelniy-podatok-2016/ (in Ukrainian).

12. Bohdan, A. (2001). Spravliannia platy za zemliu v Ukraini. Visnyk podatkovoi sluzhby Ukrainy [Payment for land in Ukraine. Bulletin of the Tax Service of Ukraine], 31: 41-52 (in Ukrainian). 


\section{S.V. Sliusarenko \& O.V. Artemenko (2021). FEATURES OF TAXATION OF AGRO-}

INDUSTRIAL ENTERPRISES IN UKRAINE. Law. Human. Environment, 12(1): 149-157.

https://doi.org/10.31548/law2021.01.017.

Summary. The article is devoted to the research of problems of taxation of enterprises of agro - industrial complex in Ukraine. Peculiarities of the tax burden on agricultural enterprises are considered. The article also identifies the features and outlines the main problems of taxation of agricultural enterprises in Ukraine. Also, the historical stages of development of agricultural tax in modern Ukraine, the evolution of changes in regulations governing the payment of taxes by agricultural enterprises are analyzed. The process of formation of the system of taxation of agricultural enterprises is investigated. The key factors in the economic sphere of the agro-industrial complex of Ukraine, special regimes of taxation of agricultural producers, the order of payment of taxes and privileges that agricultural enterprises have are identified. The procedure for payment of income tax, value added tax and specifics of the fourth group of the single tax by agricultural producers has been studied. Particular attention is paid to the procedure and requirements for the transition of agricultural enterprises to the fourth group of the single tax and the consequences of increasing the tax burden for this group. The main elements of taxes for enterprises of the agricultural sector are revealed: taxpayers; objects of taxation; tax base; tax rate; the procedure for calculating the tax; tax period; term and procedure for tax payment; term and procedure for reporting on tax calculation and payment.

It is concluded that the taxation of agro-industrial enterprises in Ukraine needs to be changed. The main goal is to make it optimal and acceptable for both the state and farmers, to simplify the system of tax administration, the establishment of tax benefits, especially for small agricultural producers, and to maintain predictability for the coming years.

Keywords: taxation, agricultural commodity producer, simplified taxation system, agricultural enterprise, single tax, land tax, income tax, value added tax, tax rate, tax period, taxpayer, IV group of single tax payers 